\title{
FOREST FIRE INSURANCE IN NORTH AMERICA WITH SPECIAL REFERENCE TO B.C. ${ }^{1}$ \\ BY WILLIAM WALTERS ${ }^{2}$
}

The material used in this essay is based on correspondence and interviews with persons actively engaged in the fields of insurance and forestry, and on selected reading.

\section{Purpose AND SCOPE OF THIS EsSAY}

Forests are one of the few kinds of property that are not generally covered by fire insurance. This is a situation which is unquestionably inimical to the application of good forestry practices. In the past, there has been no demand for, and no supply of, insurance on standing timber. Operators usually held forest land for such a short time before carrying out a program of liquidation that insurance was deemed unnecessary. On the other hand, such a tremendous amount of damage was done by fire annually, that underwriters could not have supplied insurance at a reasonable charge.

The underlying requirements for successful timber insurance, however. are steadily becoming more favorable. Increased and improved fire-prevention and control measures are reducing the fire loss to a minimum, and thus making it possible for underwriters to supply insurance, and the gradual trend towards sustained yield forestry is increasing the demand.

This essay summarizes the progress made, and discussess the difficulties and opportunities inherent in this important phase of the forest economy. An extensive study of possibilities for forest fire insurance in British Columbia, and the conclusions, are presented. It is hoped that this essay will promote a more general acceptance of the fact that standing timber can be insured at a reasonable cost, once certain conditions are fulfilled.

PRINCIPLES OF FOREST FIRE INSURANCE

The fundamental principle of insurance is indemnity. This is well illustrated by Herbert ${ }^{3}$ who defines insurance as ". . . a Social device for accumulating funds with which to meet what, from the individual's point of view, are wholly uncertain losses, by combining and transferring many individual risks to one person or group of persons." An insurance policy, then, is a contract of indemnity and does not contemplate that the insured shall profit as a result of the damage or destruction of his goods by fire.

Fire insurance is not, as is often believed, a substitute for fire protection. It merely supplements effective fire protection by absorbing the residual hazard that is left when protection has done all it can do economically.

\section{Past and PResent Status of Forest Fire Insurance}

The initial attempts to insure standing timber against fire were made in Hanover as early as 1884 . These and later attempts in other countries met with failure. In 1912, however, the Norwegian Mutual Forest Fire Insurance

\footnotetext{
1 Winning essay submitted in competition to the Western Forestry and Conservation Association Essay Contest.

2 Third Year Forestry (B.S.F.) student University of British Columbia.

3 Herbert, P. A., Forest Fire Insurance and Its Application on Michigan, Agricultural

Experiment Station, Michigan State College, 1928, Special Bulletin No. 179.
} 
Society was formed by forest owners in Norway, and for the first time successfully brought forest insurance within the economic reach of the average forest land owner. Since its establishment, it has insured 60 per cent of the 7,000,000 insurable acres in Norway. Now, in Finland, Sweden, and Germany also, standing timber can be insured at a reasonable cost.

Forest insurance on the North American continent is in the same stages of development as it was in the European and Scandinavian countries 20 to 30 years ago. Although some is being offered and written in America, it has not reached the stage of practicability. This is evident from the infinitesimal portion of the forest value that is insured.

In Canada no insurance can be obtained on standing timber. A joint stock company is at present being formed in Quebec to provide forest insurance on a mutual basis. As each policyholder will also be a stockholder, coverage will necessarily be small, at least for some years to come.

\section{DEMAND FOR FOREST FIRE INSURANCE}

Lack of Demand in the Past

Most companies which have ventured into the field of forest fire insurance in North America have subsequently withdrawn from it on the basis of "no demand". The Timberlands Mutual Forest Insurance Company of New Hampshire, for instance, was formed in 1916 and dissolved two years later. It insured selected risks, mostly mature timber which in other countries commands the lowest rates, at a flat premium rate of two per cent per year. Over the entire region covered by this company, Shepard, in 1939, found the average annual rate of burning loss on mature sawlog timber to be but 0.090 per cent, or less than one-twentieth of the premium rate charged on that area ${ }^{4}$.

Insurance rates cannot safely approach the average rate of burning losses, especially when an insurance company is in the initial stages of development. Adequate reserves must be built up to meet adverse contigencies and the expense of doing business. Even considering these expenses, however, on the basis of present data, the initial insurance rates in America were disproportionately high.

The demand in the past may have been much greater than indicated by the number of applicants for insurance, had not premium rates been prohibitive. The absence of sales promotion by insurance companies and the undeveloped state of the forest enterprise have been other factors largely responsible for the lack of demand for forest fire insurance.

\section{Present Demand}

Sustained yield forestry in North America has made rapid progress in the past two decades. This has been partly due to war-time shortages, but more so to the growing realization by timber owners that intelligently applied forestry pays. As a result of sustained yield management, large amounts of capital have been invested into forest property on a long-term basis. The forest owner, of course, is basically no different from any other kind of

4 Shepard, H. B., Forest Fire Insurance in the Northwestern States, U.S. Department of Agriculture, Technical Bulletin 651, 1939, cited in Chapman, H. H. and
Forest Valuation, McGraw-Hill Book Company, New York, 1947, p. 349 . 
property owner, and thus it is reasonable to assume that given the opportunity he would be as willing to insure his investment at a reasonable rate as other investors are.

Measuring Present Demand

In order to make a beginning in any region, a market analysis of the demand for forest fire insurance has to be undertaken. This could take the form of a careful sampling of opinion amongst timber owners practicing sustained management. Perhaps the best agency to conduct such a survey would be the government working in close cooperation with private businesses.

\section{SUPPLY OF FOREST FIRE INSURANCE}

As no attempts have been made to supply forest fire insurance on a large scale in North America, the type of organization best suited to do so is still controversial. Of the five main forms of insurance-stock companies, mutual companies, reciprocal companies, Lloyds associations and government agencies--each has advantages not inherent in the others. Successful forest insurance has been written by a mutual company in Norway, stock companies in Sweden, and government agencies in Germany.

Stock companies have taken an interest in forest insurance in America since the subject first attracted attention. This form of organization has an important advantage over the other types of private carriers in that it is usually of a greater size and can thus handle a large volume of business. In North America, where the fire hazard varies so greatly within a given region, a wide coverage is a requisite to successful insurance. If stock companies could be induced to undertake forest fire insurance, great stability could be obtained.

Perhaps the main disadvantage to this type of carrier is that it has profit as its motive, and pressure by stockholders could force the premiun rate so high as to discourage timber holders from carrying insurance.

Mutual forest fire insurance companies, in which each policyholder is also a stockholder, have been the most successful carrier in Europe. Stability with such an organization, however, comes only after the accumulation of a financial reserve, and it usually lacks sufficient capital to indemnify against losses in its initial stages of development. A mutual organization is further handicapped because it rarely has a wide geographical spread of risk.

In the reciprocal companies, the policyholder is again both insured and insurer. It differs from the mutual, however, in that the head of the company is an attorney who is given authority by the members to conduct the affairs of the organization. In the past, this type of carrier has met with success where single classes with unique technical problems have been involved. Shepard suggests that well-managed reciprocals re-insuring each other might be able to write insurance successfully."

The Lloyds Association is an association of individual underwriters, each of whom becomes personally liable for the amount of insurance for which he subscribes. This organization is not well adapted to write insurance on standing timber directly, but it would be of value as a re-insurer.

5 Shepard, H. B., Forest Fire Insurance in the Pacific Coast States, U. S. Department of Agriculture, 1937, Technical Bulletin No. 55, p. 17. 
Although no attempt has been made by the government to participate in forest fire insurance, it appears at present that a government scheme would be the most successful. Stability and a wide coverage, the two most important attributes to a successful scheme, could be obtained. If necessary, a plan inaugurated by the government could be subsidized during its initial stages to the extent of the losses incurred. It is doubtful, however, that subsidization would be needed with the extensive coverage that could be part of such a scheme.

\section{Problems in the Application of Forest Fire Insurance}

There are many obstacles which face the underwriter who is to insure forest property in North America; but although these may be difficult, they are certainly not insurmountable. Most of the difficulties are technical and can be handled at the technical level by agencies already existing in the forest and insurance industries, and in the government. Some of the more important problems are discussed below, and some suggestions for their solution are presented.

Physical Hazard

The physical hazard to the forest by fire is considered here to be the causative agent and the physical conditions in the field which affect the rate of the fire and its control. Although this hazard is not basically unlike that of other combustible property, two important factors are involved which are of relatively little importance in general fire insurance. These are the effects of topography and climate. The former affects both the rate-of-spread of the fire and the ease of control; whilst the climatic factors of precipitation, relative humidity, temperature, and air movement, markedly influence combustibility.

The conflagration hazard has been so publicized and is now so prominent in the public mind, that it tends to be over-emphasized in forest fire insurance studies. Although not, perhaps, to the same extent, there are possibilities of conflagration in the cities as there are in the forests. Underwriters limit their liability in the cities by selection and re-insurance, and in the writer's opinion, the forest conflagration hazard is susceptible to similar treatment.

The Moral Hazard

The moral hazard refers to fires started intentionally by persons with profit as their motive. Such a person may be a policyholder who intends to claim to the extent of the damage incurred, or a "firebug", who is seeking employment on a fire suppression crew.

The former is encountered in general fire insurance and presents an old problem, slightly modified. The underwriter should be able to keep this type of policyholder within bounds by applying tests of character and capacity, by safeguarding with partial insurance, and by exercising common underwriting judgment.

The employment seeker presents a more difficult problem as he has not ordinarily to be dealt with in general insurance. The number of fires started by him will generally be greatest in specific areas and during periods of finanancial depression. This moral hazard has been greatly reduced by education 
and law enforcement by government agencies. A similar, or perhaps supplementary program, carried out by insurance companies would perhaps alleviate this problem sufficiently to make it of little concern.

Valuation

Forest fire insurance valuation is concerned with determining the value of a stand of timber at a given time, to determine the approximate cost to insure it, or to find the amount of indemnity due to the owner after damage has been done to his property. The following discussion is concerned chiefly with immature timber which presents the greatest problems to forest valuation.

Forests are growing and changing communities, and thus their value is never at one level for any length of time. To determine this fluid, value, a complexity of factors, some of which depend entirely on the underwriter's judgment, must be collected and analyzed. Consideration must be given to such details as the density, composition, and age classes in the forest, its position relative to potential markets, and the current prices of timber.

The initial cruise of an area to determine the premium rate and extent of insurance will generally be made by the owner of the property. It has been found in the past that the cost of making an inspection by the underwriter prior to acceptance of a risk has proved prohibitive, and companies preferred to rely on the owner's valuation. The insurance carrier will, of course, need a general idea of timber values to decide whether or not the amount of insurance applied for is in line with the actual value. In addition, he will require a signed application warranting the applicant's valuation. Further protection is afforded the underwriter by a contract which contains a number of safeguarding clauses, such as a three-fourths loss clause to discourage overinsurance, and a coinsurance requirement to discourage underinsurance (see appendix). Rating

Rates have for a long time been a subject of great controversy in the fire insurance business. The conviction generally held by underwriters is that timberlands in the aggregate are subject to unusually high loss costs, making insurance impossible except at rates which are prohibitive. Contrary to this belief, forest economists contend that insurance can be written on standing timber at moderate rates if sufficient coverage is obtained. A low premium rate, of course is in itself a good inducement to good volume and average spread of liability. As more and more statistical data on forest fire losses become available, they are lending support to the forest economist's contention. It is apparent that unless more attractive rates are offered in the future than have been in the past, forest fire insurance will remain stationary.

\section{A Preliminary Study of Forest Fire Insurance Possibilities in British Columbia}

\section{Need for Forest Fire Insurance in British Columbia}

British Columbia lies in the greatest coniferous forest region in the world. The main industry in the Province is the timber industry and its future depends upon a continuous supply of raw materials from the forests. In 1945, Chief Justice Sloan estimated that the remaining virgin timber in British Columbia would supply our industries for another 60 years, and after this time second 
growth timber would be our only source of wood. ${ }^{\circ}$ Obviously then, in the very near future, sustained yield forestry will have to become the rule rather than the exception. The writer feels that forest fire insurance could play a large part in the promotion of better forest management. When the values he creates in standing timber are brought to a dollar and cent basis and protected by insurance, the forest owner is more likely to invest capital in improving his holdings.

Timber Values and Loss Expectancy

To date, little of the forested land in British Columbia has been surveyed or classified. The Forest Service inventory has largely been compiled by using samples, and estimates based on personal experience. Most of the figures used in this study then are approximations. Furthermore, as the timber values and fire losses used apply to the entire province, only $81 / 2 \%$ of which is in private ownership or management licenses and thus subject to insurance coverage, it must be assumed that the following relationship holds:

total loss in province

total volume of timber in province loss by private owners

volume of timber privately owned

Although this is not necessarily true, the assumption will be a close approximation.

As the basic figures are largely estimates, the results will only be approximate. They will, however, be sufficiently accurate to indicate whether or not forest fire insurance is possible in British Columbia. The study is based on the ten-year period 1940 to 1949 inclusive, although damage done by fire in the previous decade was not materially different.

The Annual Report of the British Columbia Forest Service for the year 1949 gave average annual losses resulting from forest fires as:

Merchantable timber killed or destroyed. $138,348 \mathrm{M} \mathrm{ft}$. b.m.

Immature timber burned. 47,749 acres

The salvage probability on mature timber is calculated to be 15.3 per cent. An arbitrary partial-loss probability of 60 per cent is taken for immature timber on the basis of Shepard's study in the Douglas Fir Region ${ }^{7}$.

The annual rate of net loss is accordingly taken as:

Merchantable timber $119,900 \mathrm{M} \mathrm{ft}$. b.m.

Immature timber 29,850 acres

An analysis of the British Columbia Forest inventory shows that these losses took place in a region containing approximately $109,738,200 \mathrm{M}$ ft. b.m. of merchantable timber, and 32,315,000 acres of immature timber.

Following is an integration of these figures:

\footnotetext{
6 Province of British Columbia, Report of the Commission, The Hon Gordon McG. Sloan, Chief Justice of British Columbia, Relating to the Forest Resources of B.C., Victoria, 1945.

7 Shepard, H. B., Forest Fire Insurance in the Pacific Coast States, U.S. Department of Agriculture, 1937, Technical Bulletin. No. 551, p. 137.
} 


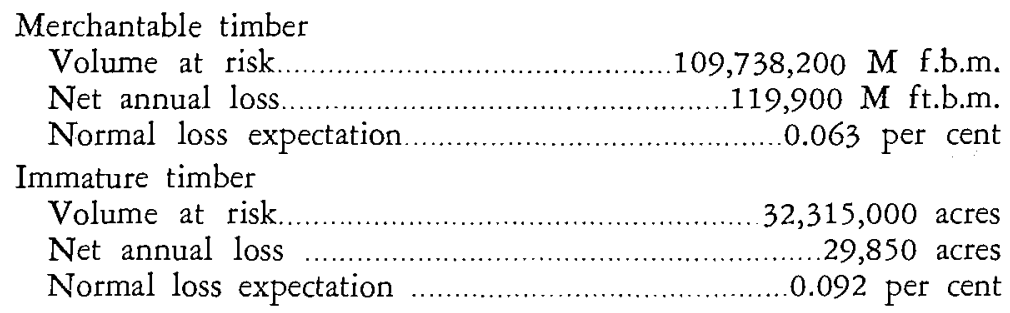

From this study, it appears that the normal loss expectation for British Columbia is 6.3 cents per 100 dollars of value on mature timber, and 9.2 cents per 100 dollars of value on immature timber. The premium rate is the normal loss expectation charge, plus expenses, profit, reserve charge for conflagration, and a safety margin charge. It is estimated that these additional costs would amount to from twenty to fifty cents, depending upon local hazard conditions. Mature timber in the province could be insured then, at an average rate of 41.3 cents per 100 dollars of value, and immature timber at an average rate of 44.2 cents per 100 dollars of value. This premium rate is from fifty to seventy per cent lower than rates now being offered by some insurance companies in North America.

\section{CONCLUSIONS AND RECOMMENDATIONS}

There is a real need for forest fire insurance in North America. Timber owners, practising sustained yield forestry, should have the same opportunity to insure their property as owners have in other commercial enterprises. Furthermore, standing timber insurance would remove some of the economic barriers to sustained yield management.

Progress in forest fire insurance has been slow for two main reasons. First, the need has grown slowly and has not been translated into effective demand. This is partly because of the prohibitive rates offered, and partly because of a lack of sales promotion. Second, forest insurance has not received enough consideration by underwriters. The subject has commanded considerable attention, but it still requires much additional study.

High rates, in so far as they result from a narrow spread of risk, can be overcome by organizations with a wide geographical coverage. In certain areas, the fire hazard is, and has been for some time, well within the requirements of sound underwriting. In these areas of low hazard, sales should be promoted to their utmost.

A stock company is better equipped to write forest fire insurance than the other types of private carriers. A government scheme would probably be still more successful could one be inaugurated.

The foregoing study indicates that the fire loss expectancy is low enough in British Columbia to permit underwriters to supply forest fire insurance. It is recommended that a more intensive study of the possibilities in this Province be made, and a thorough canvass of forest owners undertaken to determine the volume of business that could be expected.

When this need of forest owners is finally met and forest fire insurance 
becomes an accepted principle, then an important step will have been taken in the Nation's economy.

\section{WORKS CONSULTED}

Baldwin, H. L., Scandinavian Forest Fire Insurance Companies Organize a Union, Journal of Forestry, Vol. 29, pp. 134-136, 1931.

Brown, W. R., Standing Timber Insurance, Journal of Forestry, Vol. 24, pp. 243-249, 1926. Chapman, H. H. and Meyer, W. H., Forest Valuation, MeGraw-Hill Book Company, New York, 1947.

Herbert, P. A., Forest Fire Insurance and Its Application on Michigan, Agricultural Experiment Station, Michigan State College, 1928, Special Bulletin No. 179.

Province of British Columbia, Department of Lands and Forests, Report of the Forest Service, Victoria, 1949.

Province of British Columbia, Report of the Commission, The Hon Gordon McG. Sloan, Chief Justice of British Columbia Relating to the Forest Resources of B.C., Victoria, B.C., 1945. Shepard, H. B., Forest Fire Insurance in the Pacific Coast States, Superintendent of Documents, Washington, D.C., 1937. Technical Bulletin 551 .

Sparhawk, W. N., Suggestions for Rating Risks in Forestry, Journal of Forestry, Vol, 18, pp. 701-709, 1926.

Williams, E. T., Forest Insurance, Northeastern Forest Experiment Station, Pennsylvania, 19.19. Station Paper No. 26

Wright, W. G., Forest Fire Insurance, Journal of Forestry, Vol. 48, pp. 345-348, 1950.

APPENDIX

(Sample form)

MERCHANTABLE STANDING TIMBER INSURANCE ${ }^{8}$

$\$$.

on merchantable standing timber of the following varieties (and no others)

situate on his lot of ..................acres the boundaries of said lot being as follows:

Town of County of

State of

in the living trees of six inch, or greater, diameter, at four and one-half feet above the ground, and free from dryrot and other seen or unseen defects.

This policy does not cover timber growing in such locations as to render it impractical or impossible to log same at usual profit by ordinary and customary methods, and does not cover such timber or growth other than that above described.

It is further understood and agreed that this company shall be liable in case of loss if any, only for the difference between the value of the standing merchantable before the fire and the value of said merchantable timber immediately after said fire.

It is understood and agreed that the premium rate named in this policy includes a charge equal to eighty per cent of the annual premium for the additional hazard incurred during the dry season, and it is part of the consideration of this policy, and the basis upon which rate is fixed that in case

8. The Home Insurance Company. 
of cancellation by the assured the return premium shall be calculated at the customary short rates of the difference between the dry season charge and the full premium charged.

It is understood and agreed that the dry season herinabove referred to shall be any part of the months of April, May, June, July, August, September, October and November.

It is understood and agreed and made a condition of this policy that if cutting be commenced or continued on any of these lands, or any portable or permanent mill be or become erected on the premises without consent of this Company endorsed hereon, this policy shall cease to cover and shall be null and void.

It is further understood and agreed that the assured by acceptance of this policy declares the several statements and declarations in his application for insurance hereby made a part hereof, to be true, and this policy is issued upon such statements and in consideration of the premium as in this policy provided.

It is understood and agreed that this policy shall not be liable for more than $\$$ per acre of standing timber.

Reduced Rate Contribution Clause: In consideration of the reduced rate and /or form under which this policy is written, it is expressly stipulated and made a condition of this contract that in the event of loss this Company shall be liable for no greater proportion thereof than the amount hereby insured bears to ninety (90) per cent of the actual cash value of the property described herein at the time when such shall happen, nor for more than the proportion which this policy bear to the total insurance thereon.

Attached to and forming part of Policy No. 